\title{
Compliance criteria for quality concrete
}

\author{
Shamsad Ahmad, Walid A. AI-Kutti, Omar S. Baghabra AI-Amoudi *, \\ Mohammad Maslehuddin \\ Civil Engineering Department. King Fahd University of Petroleum and Minerals. P. 0. Box 1403. Dhahran 31261. Saudi Arabia
}

Received 4 May 2006; accepted 19 March 2007

Available online 3 May 2007

\begin{abstract}
With the advancement in cement technology, it is now possible to produce concrete of high strength with increased water/cement ratio. While this may satisfy the strength requirement, it is possible that the durability of such concrete is despaired. Though international organizations specify minimum cementititous materials content and maximum water/cementititous materials ratio, the quality assessment parameter is still the compressive strength. There is, however, a need to switch to permeability or chloride diffusion indices to ascertain the quality concrete. At the same time, compliance criteria for the present-day concrete need to be developed. In the reported study, an extensive experimental work was carried out to assess the compressive strength development, depth of water penetration and chloride permeability of plain, silica fume and fly ash cement concretes prepared with varying mixture proportions. The experimental data were utilized to develop statistical relationship between the mixture design parameters and the strength and durability indices. These data were also utilized to develop quality compliance criteria for concrete prepared with the crushed limestone aggregates.

(c) 2007 Elsevier Ltd. All rights reserved.
\end{abstract}

Keywords: Plain; Silica fume and fly ash cement concretes; Strength; Durability; Quality compliance criteria

\section{Introduction}

Concrete is considered to be a maintenance-free material and sound enough to resist all weather and exposure conditions. Unfortunately, this presumption has been proven to be untrue when durability problems were reported from many parts of the world [I].

Concrete mix design, including the selection of appropriate constituent materials, significantly influences the performance of both fresh and hardened concrete. A significant re-orientation in the normal mix design concepts and techniques is essential for the production of dense and impermeable concrete. Concrete mixes should, therefore, be designed using optimum coarse aggregate/total aggregate ratio, rather than using arbitrary grading. The optimum coarse aggregate/total aggregate ratio is reported to be between 0.55 and 0.70 [2,3]. The water/cement ratio

\footnotetext{
* Corresponding author. Tel.: +966 3860 2268; fax: +966 3 8602879.

E-mail address:amoudi@kfupm.edu.sa (O.S. Baghabra AI-Amoudi).
}

should be less than 0.45 , and preferably around 0.40 , to obtain a durable concrete [4]. In addition, concrete mixes should bc designed for minimum cement content. For severe freeze-thaw, deicer salt, and sulfate exposures, the cement content should not be less than $335 \mathrm{~kg} / \mathrm{m}^{3}$ [5]. The use of supplementary cementing materials, such as fly ash, silica fume and blast furnace slag, should be encouraged. Concrete with $20 \%$ cement replaced by fly ash is found to be better in resisting reinforcement corrosion compared to plain cement concrete [6]. Silica fume in the range of $6.5-8 \%$ is usually blended with cement for the production of quality concrete [7].

While the concrete quality is being improved through technological developments and increased knowledge, there is an urge to develop criteria to assess its compliance with the specifications. The compliance criteria provide helpful guidelines for assessing whether the specified concrete has actually been produced.

Considerable research [2,8-15] has been conducted on the effect of cement content, water/cement ratio, and con- 
struction practices on the strength and durability of concrete. While these data are helpful in specifying guidelines for producing durable concrete, the criteria for judging the quality of hardened concrete are not specified. Furthermore, there have been significant changes in the cement technology that have significantly affected the properties of concrete. For example, it is now possible to produce concrete of high strength with relatively high water to cementitious materials ratio due to the use of supplementary cementing materials and/or chemical admixtures. While the use of a high water/cement ratio may satisfy the strength criterion, it may not fulfill the durability requirements. Therefore, compliance criteria need to be developed to guide the end users on what properties to expect from the mix composition utilized. These also need to be revised from time to time in order to be in pace with the developments in the cement/concrete technology.

This paper presents the results of a study conducted to: (i) develop data on strength and durability of concrete produced using the normally utilized concrete design parameters, and (ii) formulate compliance criteria for quality concrete. The compliance criteria reported in this paper are developed for plain, silica fume and fly ash cement concretes produced using crushed limestone aggregates.

\section{Experimental program}

\subsection{Materials}

ASTM C 150 Type I cement, silica fume and fly ash were used in the production of concrete mixtures. In the silica fume cement concrete, $7.5 \%$ Type I cement (by mass) was replaced with silica fume while $20 \%$ Type I cement (by mass) was replaced with fly ash in the fly ash cement concrete. Crushed limestone was used as coarse aggregates while desert sand was used as fine aggregate. The coarse aggregate grading conformed to ASTM C 33 (\#7) limits. The specific gravity and water absorption of the coarse aggregates were $2.55 \%$ and $2.5 \%$, respectively. These values for the fine aggregates were $2.65 \%$ and $0.5 \%$, respectively.

\subsection{Mix parameters}

In order to develop strength and durability data over a wide range, the following design parameters were utilized in the preparation of the concrete mixtures:

\begin{tabular}{ll}
\hline $\begin{array}{l}\text { Cementitious materials } \\
\text { content: }\end{array}$ & 350 and $400 \mathrm{~kg} / \mathrm{m}^{3}$ \\
$\begin{array}{l}\text { Water/cementitious } \\
\text { materials ratio }\end{array}$ & $0.35,0.40,0.45$, and \\
$(w / \mathrm{cm}):$ & 0.50 \\
$\begin{array}{l}\text { Coarse aggregate/total } \\
\text { aggregate ratio: }\end{array}$ & 0.68 (constant for all \\
\hline
\end{tabular}

The above combinations resulted in the preparation of 24 concrete mixtures. Table 1 shows the weights of the constituent materials utilized in the preparation of the 24 concrete mixtures.

\subsection{Tests}

The concrete specimens wcre tested to determine the compressive strength development, depth of water penetration and chloride permeability. The details of the test duration, specimen geometry and test procedures are provided in Table 2.

\section{Results and discussion}

\subsection{Plain cement concrete specimens}

The compressive strength development and the durability indices, measured in terms of depth of water penetration and chloride permeavility, of plain cement concrete specimens are presented in Table 3 .

As expected, the compressive strength of all the concrete specimens increased with increasing age and decreasing $\mathrm{w} / \mathrm{cm}$ ratio. For a similar $\mathrm{w} / \mathrm{cm}$ ratio, the compressive strength of concrete specimens with a cementitious materials content of $400 \mathrm{~kg} / \mathrm{m}^{3}$ was marginally more than that of concrete specimens with a cementitious materials content of $350 \mathrm{~kg} / \mathrm{m}^{3}$.

The 28-day compressive strength of all the concrete specimens was slightly less than the values obtained from the $w / \mathrm{cm}$ ratio versus 28 -day compressive strength curve developed by ACI 211.1 [16]. This behavior could be attributed to the marginal quality of indigenous coarse aggregates available in eastern Saudi Arabia [2]. These aggregates are of recent limestone/dolomite type that are of low strength, dusty upon crushing and have high absorption. The depth of water penetration in the concrete specimens with $\mathrm{w} / \mathrm{cm}$ ratios of $0.35,0.40$, and 0.45 corresponded to "moderate water permeability", while the depth of water penetration in the concrete specimens with a $w / \mathrm{cm}$ ratio of 0.50 corresponded to "high water permeability" [17]. The chloride permeability of concrete specimens with $w / \mathrm{cm}$ ratios of $0.35,0.40$ and 0.45 was "moderate", while that of concrete specimens with a w/cm ratio of 0.50 was "high", as per AASHTO T 277 criteria.

The depth of water penetration and chloride permeability of concrete specimens prepared with a similar $w / \mathrm{cm}$ ratio decreased significantly with an increase in the cement content. The reduction in the chloride permeability with an increase in the cement content is more significant than on the water permeability. This could be attributed to the fact that the high cement content has higher impact on the chloride diffusivity than on water penetration due to the probable interaction of the $C_{3} \wedge$ content of the cement with the chloride ions. 
Table 1

Weight of constituents in the various concrete mixtures

\begin{tabular}{|c|c|c|c|c|c|c|c|}
\hline \multirow[t]{2}{*}{ Mixture no. } & \multicolumn{3}{|c|}{ Cementitious materials $\left(\mathrm{kg} / \mathrm{m}^{3}\right)$} & \multirow[t]{2}{*}{$\mathrm{w} / \mathrm{cm}$ ratio } & \multirow[t]{2}{*}{ Water $\left(\mathrm{kg} / \mathrm{m}^{3}\right)$} & \multirow{2}{*}{$\begin{array}{l}\text { Coarse aggregate } \\
\left(\mathrm{kg} / \mathrm{m}^{3}\right)\end{array}$} & \multirow{2}{*}{$\begin{array}{l}\text { Fine aggregate } \\
\left(\mathrm{kg} / \mathrm{m}^{3}\right)\end{array}$} \\
\hline & Type I cement & Silica fume & Fly ash & & & & \\
\hline 1 & 350.0 & 0.0 & 0.0 & 0.35 & 122.5 & 1378.7 & 648.8 \\
\hline 2 & 400.0 & 0.0 & 0.0 & 0.35 & 140 & 1332.8 & 627.1 \\
\hline 3 & 350.0 & 0.0 & 0.0 & 0.40 & 140 & 1366.8 & 643.0 \\
\hline 4 & 400.0 & 0.0 & 0.0 & 0.40 & 160 & 1319.2 & 620.7 \\
\hline 5 & 350.0 & 0.0 & 0.0 & 0.45 & 157.5 & 1354.9 & 637.6 \\
\hline 6 & 400.0 & 0.0 & 0.0 & 0.45 & 180 & 1305.6 & 614.4 \\
\hline 7 & 350.0 & 0.0 & 0.0 & 0.50 & 175 & 1343.0 & 632.0 \\
\hline 8 & 400.0 & 0.0 & 0.0 & 0.50 & 200 & 1292.0 & 608.0 \\
\hline 9 & 323.8 & 26.3 & 0.0 & 0.35 & 122.5 & 1490.5 & 701.4 \\
\hline 10 & 370.0 & 30.0 & 0.0 & 0.35 & 140 & 1440.9 & 678.0 \\
\hline 11 & 323.8 & 26.3 & 0.0 & 0.40 & 140 & 1477.6 & 695.1 \\
\hline 12 & 370.0 & 30.0 & 0.0 & 0.40 & 160 & 1425.8 & 671.0 \\
\hline 13 & 323,8 & 26.3 & 0.0 & 0.45 & 157.5 & 1464.8 & 689.3 \\
\hline 14 & 370.0 & 30.0 & 0.0 & 0.45 & 180 & 1411.5 & 664.1 \\
\hline 15 & 323.8 & 26.3 & 0.0 & 0.50 & 175 & 1451.9 & 682.9 \\
\hline 16 & 370.0 & 30.0 & 0.0 & 0.50 & 200 & 1396.8 & 657.2 \\
\hline 17 & 280.0 & 0.0 & 70.0 & 0.35 & 122.5 & 1723.4 & 811.0 \\
\hline 18 & 320.0 & 0.0 & 80.0 & 0.35 & 140 & 1666.0 & 783.9 \\
\hline 19 & 280.0 & 0.0 & 70.0 & 0.40 & 140 & 1708.5 & 804.0 \\
\hline 20 & 320.0 & 0.0 & 80.0 & 0.40 & 160 & 1649.0 & 775.9 \\
\hline 21 & 280.0 & 0.0 & 70.0 & 0.45 & 157.5 & 1693.6 & 796.9 \\
\hline 22 & 320.0 & 0.0 & 80.0 & 0.45 & 180 & 1632.0 & 768.0 \\
\hline 23 & 280.0 & 0.0 & 70.0 & 0.50 & 175 & 1678.8 & 790.0 \\
\hline 24 & 320.0 & 0.0 & 80.0 & 0.50 & 200 & 1615.0 & 760.0 \\
\hline
\end{tabular}

Table 2

Details of tests, specimens and test standards

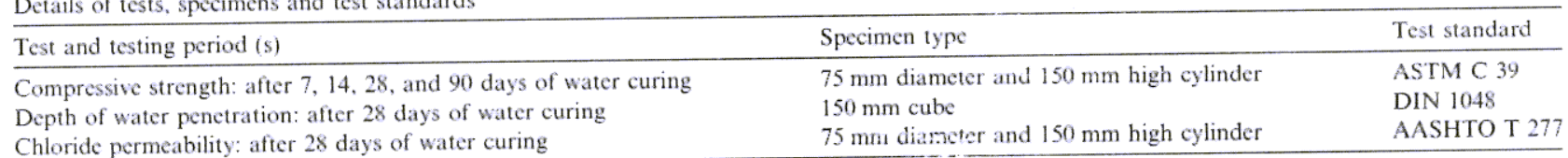

Table 3

Summary of test results for plain cement conerete specimens

\begin{tabular}{|c|c|c|c|c|c|c|c|c|}
\hline \multirow[t]{2}{*}{ Mixture no. } & \multirow{2}{*}{$\begin{array}{l}\text { Cementitious materials } \\
\text { content }\left(\mathrm{kg} / \mathrm{m}^{3}\right)\end{array}$} & \multirow[t]{2}{*}{$\mathrm{w} / \mathrm{cm}$ ratio } & \multicolumn{4}{|c|}{ Compressive strength (MPa) after } & \multirow{2}{*}{$\begin{array}{l}\text { Depth of water } \\
\text { penetration }(\mathrm{mm})\end{array}$} & \multirow{2}{*}{$\begin{array}{l}\text { Chloride } \\
\text { permeability (C) }\end{array}$} \\
\hline & & & 7 days & 14 days & 28 days & 90 days & & \\
\hline 1 & 350 & 0.35 & 32.1 & 35.7 & 43.1 & 45.7 & 41 & 2875 \\
\hline 2 & 400 & 0.35 & 33.7 & 37.9 & 45.3 & 46.9 & 36 & 2445 \\
\hline 3 & 350 & 0.40 & 27.0 & 34.2 & 39.5 & 42.5 & 47 & 3639 \\
\hline 4 & 400 & 0.40 & 28.1 & 35.0 & 41.0 & 43.7 & 44 & 3271 \\
\hline 5 & 350 & 0.45 & 24.3 & 31.3 & 34.9 & 38.2 & 50 & 3820 \\
\hline 6 & 400 & 0.45 & 25.6 & 32.4 & 35.9 & 39.6 & 48 & 3593 \\
\hline 7 & 350 & 0.50 & 22.0 & 27.1 & 31.6 & 34,6 & 89 & 5614 \\
\hline 8 & 400 & 0.50 & 23.5 & 28.5 & 33.9 & 36.4 & 82 & 4150 \\
\hline
\end{tabular}

\subsection{Silica fume cement concrete specimens}

The strength development, depth of water penetration and chloride permeability of silica fume cement concrete specimens is summarized in Table 4 . As expected, the compressive strength increased with increasing curing period and decreasing $\mathrm{w} / \mathrm{cm}$ ratio. The compressive strength of the concrete specimens prepared with a cementititous materials content of $400 \mathrm{~kg} / \mathrm{m}^{3}$ was more than that of the concrete specimens prepared with a cementitious materials content of $350 \mathrm{~kg} / \mathrm{m}^{3}$.

The 28-day compressive strength was either equal or slightly morc than the strength obtained from the $w / \mathrm{cm}$ ratio versus 28 -day compressive strength curve developed 
Table 4

Summary of test results for silica fume cement concrete specimens

\begin{tabular}{|c|c|c|c|c|c|c|c|c|}
\hline \multirow[t]{2}{*}{ Mixture no. } & \multirow{2}{*}{$\begin{array}{l}\text { Cementitious materials } \\
\text { content }\left(\mathrm{kg} / \mathrm{m}^{3}\right)\end{array}$} & \multirow[t]{2}{*}{$w / \mathrm{cm}$ ratio } & \multicolumn{4}{|c|}{ Compressive strength (MPa) after } & \multirow{2}{*}{$\begin{array}{l}\text { Depth of water } \\
\text { penetration ( } \mathrm{mm})\end{array}$} & \multirow{2}{*}{$\begin{array}{l}\text { Chloride } \\
\text { permeability (C) }\end{array}$} \\
\hline & & & 7 days & 14 days & 28 days & 90 days & & \\
\hline 9 & 350 & 0.35 & 36.4 & 40.3 & 46.2 & 49.7 & 23 & 820 \\
\hline 10 & 400 & 0.35 & 37.8 & 42.8 & 48.1 & 51.2 & 21 & 782 \\
\hline 11 & 350 & 0.40 & 31.0 & 37.0 & 42.8 & 47.5 & 35 & 995 \\
\hline 12 & 400 & 0.40 & 33.2 & 38.4 & 44.2 & 48.1 & 31 & 866 \\
\hline 13 & 350 & 0.45 & 29.2 & 35.5 & 39.1 & 44.9 & $4 !$ & 1329 \\
\hline 14 & 400 & 0.45 & 30.2 & 36.0 & 41.2 & 46.2 & 35 & 1149 \\
\hline 15 & 350 & 0.50 & 26.5 & 32.6 & 35.9 & 38.7 & 50 & 2591 \\
\hline 16 & 400 & 0.50 & 28.5 & 33.7 & 36.2 & 41.9 & 44 & 2019 \\
\hline
\end{tabular}

by ACI 211.1 [16]. The depth of water penetration in the concrete specimens with a $\mathrm{w} / \mathrm{cm}$ ratio of 0.35 corresponded to "low water permeability", while the depth of water penetration in the concrete specimens with $w / \mathrm{cm}$ ratios of 0.40 , 0.45 and 0.50 corresponded to "moderate water permeability" [17].

The chloride permeability of the concrete specimens with w/cm ratios of 0.35 and 0.40 was "very low", while that of the concrete specimens with w/cm ratios of 0.45 and 0.5 was "low" and "moderate", respectively, as per AASHTO T 277 criteria. The depth of water penetration and chloride permeability decreased with an increase in the cementitious materials content. The decrease in the chloride permeability, with an increase in the cementitious materials content, was more significant than the depth of water penetration.

\subsection{Fly ash cement concrete specimens}

The compressive strength development, depth of water penetration and chloride permeability in the fly ash cement concrete specimens is summarized in Table 5. A normal trend of variation of strength with $\mathrm{w} / \mathrm{cm}$ ratio and curing period could be noted from the data in Table 5. The compressive strength of concrete specimens with a cementitious materials content of $400 \mathrm{~kg} / \mathrm{m}^{3}$ was slightly more than that of concrete specimens with a cementitious materials content of $350 \mathrm{~kg} / \mathrm{m}^{3}$.
The 28-day compressive strength was significantly lower than the strength obtained from the $\mathrm{w} / \mathrm{cm}$ ratio versus 28 day compressive strength curve developed by ACI 211.1 [16]. Further, the 28-day compressive strength of fly ash cement concrete was less than that of plain cement concrete (Table 3). However, the 90-day compressive strength of fly ash cement concrete specimens was slightly more than that of plain cement concrete specimens. The lower strength of fly ash cement concrete specimens after 28 days of curing may be attributed to the slow pozzolanic reaction of the fly ash utilized in the preparation of the concrete specimens.

The depth of water peneuation was "moderate" for all the concrete specimens [17]. The chloride permeability for concrete specimens with w/cm ratios of 0.35 and 0.40 was "low", while for the concreie specimens with $\mathrm{w} / \mathrm{cm}$ ratios of 0.45 and 0.50 , it was "moderate", as per AASHTO T 277 criteria. The depth of water penetration and chloride permeability decreased with an increase in the quantity of the cementitious materials. The reduction in the chloride permeability with an increase in the cementitious materials content is more significant than the depth of water penetration.

\section{Correlations between test results and concrete mix parameters}

The results of compressive strength, chloride permeability and depth of water penetration were utilized to establish

Table 5

Summary of test results for fly ash eement concrete specimens

\begin{tabular}{|c|c|c|c|c|c|c|c|c|}
\hline \multirow[t]{2}{*}{ Mixture no. } & \multirow{2}{*}{$\begin{array}{l}\text { Cementitious materials } \\
\text { content }\left(\mathrm{kg} / \mathrm{m}^{3}\right)\end{array}$} & \multirow[t]{2}{*}{$w / \mathrm{cm}$ ratio } & \multicolumn{4}{|c|}{ Compressive strength ( $\mathrm{MPa}$ ) after } & \multirow{2}{*}{$\begin{array}{l}\text { Depth of water } \\
\text { penetration }(\mathrm{mm})\end{array}$} & \multirow{2}{*}{$\begin{array}{l}\text { Chloride } \\
\text { permeability (C) }\end{array}$} \\
\hline & & & 7 days & 14 days & 28 days & 90 diays & & \\
\hline 17 & 350 & 0.35 & 24.5 & 27.5 & 36.7 & 47.5 & 32 & 1603 \\
\hline 18 & 400 & 0.35 & 26.1 & 28.6 & 37.6 & 48.8 & 31 & 1477 \\
\hline 19 & 350 & 0.40 & 22.8 & 25.0 & 36.2 & 428 & 44 & 1769 \\
\hline 20 & 400 & 0.40 & 23.7 & 26.5 & 36.5 & 45.2 & 38 & 1630 \\
\hline 21 & 350 & 0.45 & 20.2 & 22.5 & 31.6 & 39.2 & 46 & 2510 \\
\hline 22 & 400 & 0.45 & 21.0 & 23.9 & 32.9 & 40.7 & 45 & 2220 \\
\hline 23 & 350 & 0.50 & 16.1 & 18.1 & 23.7 & 35.1 & 57 & 3548 \\
\hline 24 & 400 & 0.50 & 16.6 & 19.0 & 25.0 & 36.9 & 51 & 2750 \\
\hline
\end{tabular}


the best possible correlations between the mix parameters and the concrete properties. Minitab 13 - a statistical package was used to analyze the data and to develop the regression models for plain, silica fume and fly ash cement concretes.

\subsection{Correlation between compressive strength and concrete mix parameters}

Based on the analysis of variance (ANOVA), the significance of each mix design factor on the compressive strength was evaluated. Both $\mathrm{w} / \mathrm{cm}$ ratio and cementitious materials content were found to have a significant effect on compressive strength. However, w/cm ratio had major effect on strength. Table 6 shows all the regression models correlating the compressive strength with concrete mix parameters; such as $\mathrm{w} / \mathrm{cm}$ ratio and cementitious materials content, for different curing periods.

\subsection{Correlation between chloride permeability and concrete mix parameters}

Based on the analysis of variance of the test data, it was noted that both the cementitious materials content and the $\mathrm{w} / \mathrm{cm}$ ratio had a significant effect on the chloride permeability. The following models best represent the relationships between the concrete parameters and chloride permeability:

$P_{\mathrm{cl}}=10467 \mathrm{w} / \mathrm{cm}-6.83 \mathrm{~cm}+1649 ; R^{2}=0.95$

for plain cement concrete

$P_{\mathrm{cl}}=9641 \mathrm{w} / \mathrm{cm}-4.59 \mathrm{~cm}-1055 ; R^{2}=0.82$

for silica fume cement concrete

$P_{\mathrm{cl}}=10980 \mathrm{w} / \mathrm{cm}-6.74 \mathrm{~cm}+50 ; R^{2}=0.90$

for fly ash cement concrete

$P_{\mathrm{cl}}$ is the chloride permeability in Coulombs,

$\mathrm{w} / \mathrm{cm}$ is the water-cementitious materials ratio; and,

$\mathrm{cm}$ is the cementitious materials content, $\mathrm{kg} / \mathrm{m}^{3}$.

\subsection{Correlation between depth of water penetration and} concrete mix parameters

The depth of water penetration in plain and blended cement concretes, after 28 days of water curing, was analyzed to develop best-fit models correlating it with the concrete mix parameters, such as $\mathrm{w} / \mathrm{cm}$ ratio and cementitious materials content. The analysis of variance of the results indicated that the $w / \mathrm{cm}$ ratio mainly affected the depth of water penetration for all the three types of concrete and the following relationships were noted:

$d=295 \mathrm{w} / \mathrm{cm}-0.095 \mathrm{~cm}-34.4 ; R^{2}=0.84$

for plain cement concrete

$d=186 \mathrm{w} / \mathrm{cm}-0.08 \mathrm{~cm}-12.8 ; R^{2}=0.98$

for silica fume cement concrete

$d=144 \mathrm{w} / \mathrm{cm}-0.07 \mathrm{~cm}+8.1 ; R^{2}=0.96$

for fly ash cement concrete

$d$ is the depth of water penetration( $\mathrm{mm})$,

$\mathrm{w} / \mathrm{cm}$ is the water-cenimentitious materials ratio; and, $\mathrm{cm}$ is the cementitious materials content $\left(\mathrm{kg} / \mathrm{m}^{3}\right)$.

\subsection{Relationship betwcen compressive strength and chloride permeability}

Table 7 summarizes the relationship between the 28-day compressive strength and the chloride permeability in plain and blended cement concretes after 28 days of water curing. From these data, it could be noted that for a similar compressive strength, the chloride permeability in blended cement concretes was less than that of plain cement concrete. For compressive strength of less than $35 \mathrm{MPa}$, the chloride permeability in plain cement concrete was "high", while it was "moderate" in the silica fume and fly ash cement concretes. For compressive strength in the range of $35-40 \mathrm{MPa}$, the chloride permeability in plain cement concrete was "moderate", while it was "low" in silica fume and fly ash cement concretes. Further, the chloride permeability of silica fume cement concrete decreased from

Table 6

Relationships between compressive strength and concrete mix parameters

\begin{tabular}{llll}
\hline $\begin{array}{l}\text { Curing time } \\
\text { (days) }\end{array}$ & Plain cement concrete & Silica fume cement concrete & Fly ash cement concrete \\
\hline 7 & & & \\
& $f_{c_{7}=44.8+0.027 \mathrm{~cm}-66.1 \mathrm{w} / \mathrm{cm}}$ & $f c_{7}=45.7+0.02 \mathrm{~cm}-62.4 \mathrm{w} / \mathrm{cm}$ & $f c_{7}=39.3+0.019 \mathrm{~cm}-59 \mathrm{w} / \mathrm{cm}$ \\
& $\left(R^{2}=0.95\right)$ & $\left(R^{2}=0.93\right)$ & $\left(R^{2}=0.97\right)$ \\
& $f_{c_{14}=47.7+0.028 \mathrm{~cm}-59.5 \mathrm{w} / \mathrm{cm}}$ & $f c_{14}=49.8+0.025 \mathrm{~cm}-54.3 \mathrm{w} / \mathrm{cm}$ & $f c_{14}=41.1+0.024 \mathrm{~cm}-62.1 \mathrm{w} / \mathrm{cm}$ \\
& $\left(R^{2}=0.94\right)$ & $\left(R^{2}=0.96\right)$ & $\left(R^{2}=0.97\right)$ \\
& $f_{c_{28}=58.3+0.035 \mathrm{~cm}-78.4 \mathrm{w} / \mathrm{cm}}$ & $f c_{28}=62.2+0.022 \mathrm{~cm}-73.3 \mathrm{w} / \mathrm{cm}$ & $f c_{28}=61.5+0.019 \mathrm{~cm}-85 \mathrm{w} / \mathrm{cm}$ \\
& $\left(R^{2}=0.98\right)$ & $\left(R^{2}=0.97\right)$ & $\left(R^{2}=0.88\right)$ \\
90 & $f c_{90}=61.6+0.028 \mathrm{~cm}-73.2 \mathrm{w} / \mathrm{cm}$ & $f c_{90}=61.4+0.03 \mathrm{~cm}-65.4 \mathrm{w} / \mathrm{cm}$ & $f c_{90}=65.8+0.03 \mathrm{~cm}-82 \mathrm{w} / \mathrm{cm}$ \\
& $\left(R^{2}=0.99\right)$ & $\left(R^{2}=0.93\right)$ & $\left(R^{2}=0.99\right)$ \\
\hline
\end{tabular}

$f_{6}, f_{14}, f_{28}$, and $f_{6,0}$ Strength of concrete (MPa) after $7,14,28$, and 90 days of water curing, respectively, w/cm: Water to cementitious materials ratio $\mathrm{cm}$ : Cementitious materials content $\left(\mathrm{kg} / \mathrm{m}^{3}\right), R^{2}$ : Coefficient of determination. 
Table 7

Relationship between 28-day compressive strength and chloride permeability

\begin{tabular}{llll}
\hline Compressive strength (MPa) & \multicolumn{3}{l}{ Chloride permeability (C) } \\
\cline { 2 - 4 } & Plain & Silica fume & Fly ash \\
\hline$<35$ & High & Moderate & Moderate \\
$35-40$ & Moderate & Low & Low \\
$40-50$ & Moderate & Very low & $--^{\text {a }}$ \\
\hline
\end{tabular}

${ }^{3}$ Fly ash cement concrete could not attain strength higher than $40 \mathrm{MPa}$ at 28 day.

"low" to "very low" (i.e. less than $1000 \mathrm{C}$ ) for compressive strength of more than $40 \mathrm{MPa}$. However, such a reduction in the chloride permeability was not noted in the fly ash and plain cement concretes, even though the compressive strength was high.

\subsection{Relationship between compressive strength and depth of water penetration}

The relationships between the compressive strength and depth of water penetration in plain and silica fume cement concretes after 28 days of water curing are summarized in Table 8. From these data, it could be observed that for compressive strength of less than $35 \mathrm{MPa}$, the water permeability in the plain cement concrete was "high", while it was "moderate" in both the silica fume and fly ash cement concretes. Further, for compressive strength in the range of $35-40 \mathrm{MPa}$, the depth of water penetration was moderate in both plain and blended cement concretes. However, the depth of water penetration of silica fume cement concrete decreased from "moderate" to "low" (i.e. less than $30 \mathrm{~mm}$ ) for compressive strength of more than $40 \mathrm{MPa}$. Such a reduction in the depth of water penetration was not noted in plain cement concretes, even though the compressive strength was "high".

From these results, it could be observed that the effect of blended cements on the depth of water penetration in concrete could not be detected in concrete with compressive strength of less than $40 \mathrm{MPa}$, while the superior performance of silica fume cement concrete in decreasing the depth of water penetration could be noticed for concrete with compressive strength of more than $40 \mathrm{MPa}$. The performance of fly ash cement concrete was not very clear. For different levels of compressive strength, the depth of water of penetration in this type of concrete was moderate. This

Table 8

Relationship between 28-day compressive strength and depth of water penetration

\begin{tabular}{llll}
\hline Compressive strength $(\mathrm{MPa})$ & \multicolumn{3}{l}{ Depth of water penetration $(\mathrm{mm})$} \\
\cline { 2 - 4 } & Plain & Silica fume & Fly ash \\
\hline$<35$ & High & Moderate & Moderate \\
$35-40$ & Moderate & Moderate & Moderate \\
$40-50$ & Moderate & Low & $-{ }^{\mathrm{a}}$ \\
\hline
\end{tabular}

${ }^{a}$ Fly ash cement concrete could not attain strength higher than $40 \mathrm{MPa}$ at 28 day. could be explained by the fact that the depth of water penetration was determined only after 28 days of water curing and fly ash cement concrete needs further curing to produce very low permeability [15].

\section{Compliance criteria}

Based on the data developed in this study, compliance criteria were developed for the three properties investigated, namely compressive strength, depth of water penetration and chloride permeability. Tables 9-11 show the compliance criteria for the compressive strength. It should be mentioned that these compliance criteria are for concrete produced using crushed limestone aggregate available in eastern Saudi Arabia and may not be valid for other types of aggregates. The developed compliance criteria represent the variation in the concrete mixture composition, namely the $w / \mathrm{cm}$ ratio and the cementitious materials content. Higher stringths have been ascribed to the silica fume cement concretes as it is generally known that silica fume, being a highly reactive supplementary cementing material, does not hamper the compressive strength development.

Table 9

Compliance criteria for compressive strength for plain cement concrete

\begin{tabular}{llllll}
\hline w/cm Ratio & $\begin{array}{l}\text { Cement content } \\
\left(\mathrm{kg} / \mathrm{m}^{3}\right)\end{array}$ & \multicolumn{5}{c}{ Compressive strength (MPa) } \\
\cline { 3 - 6 } & 350 & $30-35$ & $35-40$ & $40-45$ & $45-50$ \\
\hline 0.35 & 400 & $30-35$ & $35-40$ & $40-45$ & $45-50$ \\
& & & & & \\
0.40 & 350 & $25-30$ & $30-35$ & $35-40$ & $40-45$ \\
& 400 & $25-30$ & $30-35$ & $35-40$ & $40-45$ \\
0.45 & 300 & $20-25$ & $25-30$ & $30-35$ & $35-40$ \\
& 350 & $20-25$ & $30-35$ & $30-35$ & $35-40$ \\
& 400 & $25-30$ & $30-35$ & $35-40$ & $35-40$ \\
0.50 & 350 & & & & \\
& 400 & $20-25$ & $25-30$ & $30-35$ & $30-35$ \\
& & $20-25$ & $25-30$ & $30-35$ & $30-35$ \\
\hline
\end{tabular}

Table 10

Compliance criteria for compressive strength for silica fume cement concrete

\begin{tabular}{|c|c|c|c|c|c|}
\hline \multirow[t]{2}{*}{ w/cm Ratio } & \multirow{2}{*}{$\begin{array}{l}\text { Cementitious } \\
\text { materials } \\
\text { content, } \mathrm{kg} / \mathrm{m}^{3}\end{array}$} & \multicolumn{4}{|c|}{ Compressive strength (MPa) } \\
\hline & & 7 days & 14 days & 28 days & 90 days \\
\hline \multirow[t]{2}{*}{0.35} & 350 & $35-40$ & $40-45$ & $45-50$ & $45-50$ \\
\hline & 400 & $35-40$ & $40-45$ & $45-50$ & $50-55$ \\
\hline \multirow[t]{2}{*}{0.40} & 350 & $30-35$ & $35-40$ & $40-45$ & $45-50$ \\
\hline & 400 & $30-35$ & $35-40$ & $40-45$ & $45-50$ \\
\hline \multirow[t]{3}{*}{0.45} & 300 & $25-30$ & $30-35$ & $30-40$ & $40-45$ \\
\hline & 350 & $25-30$ & $30-35$ & $35-40$ & $40-45$ \\
\hline & 400 & $25-30$ & $30-35$ & $35-40$ & $40-45$ \\
\hline \multirow[t]{2}{*}{0.50} & 350 & $25-30$ & $30-35$ & $30-35$ & $35-40$ \\
\hline & 400 & 2530 & $30-35$ & $30-35$ & $35-40$ \\
\hline
\end{tabular}


Table 11

Compliance criteria for compressive strength for fly ash cement concrete

\begin{tabular}{llllll}
\hline w/cm Ratio & $\begin{array}{l}\text { Cementitious } \\
\text { materials } \\
\text { content }\left(\mathrm{kg} / \mathrm{m}^{3}\right)\end{array}$ & \multicolumn{4}{c}{ Compressive strength (MPa) } \\
\cline { 3 - 6 } & 350 & $20-25$ & $25-30$ & $35-40$ & $40-50$ \\
\hline 0.35 & 400 & $20-25$ & $25-30$ & $35-40$ & $40-50$ \\
& & & & & \\
0.40 & 350 & $20-25$ & $25-30$ & $30-40$ & $40-45$ \\
& 400 & $20-25$ & $25-30$ & $30-40$ & $40-45$ \\
0.45 & 300 & $15-20$ & $20-25$ & $25-30$ & $30-40$ \\
& 350 & $15-20$ & $20-25$ & $25-30$ & $30-40$ \\
& 400 & $15-20$ & $20-25$ & $25-30$ & $30-40$ \\
0.50 & 350 & $15-20$ & $20-25$ & $25-30$ & $30-35$ \\
& 400 & $15-20$ & $20-25$ & $25-30$ & $30-35$ \\
\hline
\end{tabular}

Table 12

Compliance criteria for chloride permeability for plain and blended cement concretes

\begin{tabular}{|c|c|c|c|c|}
\hline \multirow{2}{*}{$\begin{array}{l}\text { w/cm } \\
\text { Ratio }\end{array}$} & \multirow{2}{*}{$\begin{array}{l}\text { Cementitious } \\
\text { materials } \\
\text { content }\left(\mathrm{kg} / \mathrm{m}^{3}\right)\end{array}$} & \multicolumn{3}{|c|}{ Chloride permeability (C) } \\
\hline & & $\begin{array}{l}\text { Plain } \\
\text { cement } \\
\text { concrete }\end{array}$ & $\begin{array}{l}\text { Silica fume } \\
\text { cement } \\
\text { concrete }\end{array}$ & $\begin{array}{l}\text { Fly ash } \\
\text { cement } \\
\text { concrete }\end{array}$ \\
\hline \multirow[t]{2}{*}{0.35} & 350 & $2500-3000$ & $700-1000$ & $1300-2000$ \\
\hline & 400 & $2000-2500$ & $600-1000$ & $1300-1600$ \\
\hline \multirow[t]{2}{*}{0.40} & 350 & $3000-4000$ & $800-1200$ & $1600-2000$ \\
\hline & 400 & $2500-3500$ & $800-1000$ & $1600-1800$ \\
\hline \multirow[t]{3}{*}{0.45} & 300 & $3500-4500$ & $1000-1500$ & $2000-3000$ \\
\hline & 350 & $3500-4000$ & $1000-1500$ & $2000-3000$ \\
\hline & 400 & $3500-4000$ & $900-1500$ & $2000-2500$ \\
\hline \multirow[t]{2}{*}{0.50} & 350 & $5000-6000$ & $2500-3000$ & $2500-4500$ \\
\hline & 400 & $4000-4500$ & $1500-2500$ & $2200-3500$ \\
\hline
\end{tabular}

Table 13

Compliance criteria for depth of water penetration for plain and blended cement concretes

\begin{tabular}{lllll}
\hline $\begin{array}{l}\text { W/cm } \\
\text { Ratio }\end{array}$ & $\begin{array}{l}\text { Cementitious } \\
\text { materials } \\
\text { content }\left(\mathrm{kg} / \mathrm{m}^{3}\right)\end{array}$ & \multicolumn{3}{l}{ Water penetration depth $(\mathrm{mm})$} \\
\cline { 3 - 5 } & $\begin{array}{l}\text { Plain } \\
\text { cement } \\
\text { concrete }\end{array}$ & $\begin{array}{l}\text { Silica fume } \\
\text { cement } \\
\text { concrete }\end{array}$ & $\begin{array}{l}\text { Fly ash } \\
\text { cement } \\
\text { concrete }\end{array}$ \\
\hline 0.35 & 350 & $35-45$ & $20-30$ & $20-35$ \\
& 400 & $35-40$ & $20-25$ & $20-35$ \\
0.40 & 350 & $40-50$ & $30-40$ & $40-45$ \\
& 400 & $40-45$ & $30-35$ & $35-40$ \\
0.45 & 300 & $50-60$ & $40-50$ & $45-50$ \\
& 350 & $45-50$ & $35-45$ & $45-50$ \\
& 400 & $40-45$ & $30-35$ & $35-45$ \\
0.50 & 350 & & & $50-60$ \\
& 400 & $75-90$ & $40-50$ & $40-55$ \\
\hline
\end{tabular}

However, in the case of fly ash cement concrete, a lower strength is expected than the plain and silica fume cement concretes for similar mixture design parameters. This may be ascribed to the fact that the fly ash used in the preparation of concrete specimens apparently yielded a lower compressive strength compared to plain and silica fume cement concrete specimens. However, fly ash from other sources may contribute to compressive strength at a much rapid rate due to the significant variation in the pozzolanic activity of fly ash.

Table 12 presents the range of chloride permeability values to be expected from the plain, silica fume and fly ash cement concrete specimens tested in this study, while Tablo 13 shows the depth of water penetration. These data are useful for assessing the quality of concrete prepared with the mix design parameters utilized in this study. Again, a cautionary note, these values are for crushed limestone aggregates and may not be valid for other types of aggregates.

\section{Conclusions}

The effect of mix design parameters on the compressive strength, depth of water penetration and chloride permeability was investigated with a view to develop possible relationships between these parameters and to sugges compliance criteria.

As expected, the compressive strength, depth of water penetration and chloride permeability were significantly influenced by the type of cementitious materials and $w / \mathrm{cm}$ ratio. The quantity of the cementitious materials content did not significantly influence the aforesaid properties, probably due to the narrow difference between the two values investigated, nameiy 350 and $400 \mathrm{~kg} / \mathrm{m}^{3}$.

The compressive strength and durability characteristics, measured in terms of depth of water penetration and chloride permeability, of silica funine cement concretes were better than those of plain cement concrete specimens. A delay in strength gain was noted in the fly ash cement concrete specimens.

Statistical analyses of the data indicated a significant effect of the w/cm ratio for all types of concretes up to a curing period of 28 days. At about 90 days, this effect tended to decrease. Relationships between the mix design parameters and compressive strength, depth of water penetration and chloride permeability were developed. A high coefficient of corrclation $\left(R^{2}\right)$ of 0.8 indicates a good correlation between the experimental and theoretical values.

Compliance criteria for compressive strength, depth of water penetration and chloride permeability are presented in Tables 9-13. These guidelines are strictly related to crushed limestone aggregates and similar guidelines may need to be developed for other types of aggregate.

\section{Acknowledgement}

The authors gratefully acknowledge the financial support received for this research under grant ARI-022 from the Research Insticuic at King Fahd University of Petroleum and Minerals, Dhahran, Saudi Arabia. 


\section{References}

[1] Al-Amoudi OSB, Maslehuddin M. Concrete protection in aggressive media (leader paper). In: Dhir RK, Jones MR, editors. Concrete in the service of mankind: concrete repair, rehabilitation and protection. London: E\&FN Spon; 1996. p. 141-54.

[2] Maslehuddin M, Rasheeduzzafar, Al-Mana AI. The effect of aggregate grading and admixture on concrete durability. In: Procecdings of 3rd Saudi engineering conference, King Saud University: Riyadh ; 1991. p. 103-9.

[3] Soudki KA, El-Salakawy EF, Elkum NB. Full factorial optimization of concrete mix design for hot climates. ASCE J. Mate. Civil Eng. 2001;13(6):427-33.

[4] Al-Amoudi OSB, Maslehuddin M, Rasheeduzzafar. Permeability of concrete: influential factors. In: Procedings of 4th international conference on deterioration and repair of reinforced concrete in the arabian Gulf, Bahrain; 1993. p. 717-33.

[5] ACl Committee 302.1R-96. Guide for concrete floor and slab construction. American Concrete Institute, Farmington Hills (MI); 1996.

[6] Maslehuddin M, Saricimen H, Al-Mana Al. Effect of fly ash addition on the corrosion resisting characteristics of concrete. $\mathrm{ACl}$ Mate. J. 1987:42-50.

[7] Khayat KH, Aitcin PC. Silica fume in concrete - an overview. In: Malhotra VM, editor. ACI SP-132 on Fly ash, silica fumc, slag, and natural pozzolans in concrete, Detroit (Michigan): 1993. p. 835-72.

[8] Rasheeduzzafar, Al-Ghatani AS, Al-Saadoun SS. Influence of construction practices on concrete durability. ACI Mate. J. 1989;86(6): $566-75$.

[9] Hussain SE. Mechanisms of high durability performance of plain and blended cements. PhD Thesis, Department of Civil Engineering, King
Fahd University of Petroleum and Minerals, Dhahran, Saudi Arabia; 1991.

[10] Hanif M. Performance of pozzolan cement concrete in a high chloride-sulfate envisument. MS Thesis, Department of Civil Engineering, King Fald Iniversity of Petroleum and Minerals. Dhahran, Saudi Arabia; 1982

[11] Al-Gahtani AS An investigation of corrosion of reinforcement in concrete in the Eastern Province of Saudi Arabia. MS Thesis, Department of Civil Engineering. King Fahd University of Petroleum and Minerals, Dhahran, Saudi Arabia; 1981.

[12] Maslehuddin M, Al-Mana AI, Saricimen H, Shamim M. Corrosion of reinforving steel in concrete containing slag or pozzolans. Cement Conc. Aggregates 1990;12(1):24-31.

[13] Al-Amoudi OSB. Siudies on soil-foundation interaction in the Sabkha environment of Eastern Province of Saudi Arabia. PhD Thesis Vols. 1 and II, Department of Civil Engineering, King Fahd University of Petroleum and Minerals, Dhahran, Saudi Arabia; 1992.

[14] Al-Amoudi OSB, Abduljauwad SN, Rashecduzzafar, Maslehuddin M. Effect of chloride and sulfate contamination in soils on corrosion of steel and concrete. Transp. Res. Record 1992;1345: $67-73$.

[15] Al-Amoudi OSB. Studies on the evaluation of permeability and corrosion resisting characteristics of Portland pozzolan concretes. MS Thesis, Department of Civil Fneineering. King Fahd University of Petroleum and Minerals, Dhahran, Saudi Arabia; 1985.

[16] ACI Committec 211.1. Standard practice for selecting proportions for normal, heavywcight and mass concrete. American Concrete Institute, Farmington Hills (Michigan); 1991.

[17] The Concrete Society. Permeability testing of site concrete-a review of methods and experience. Technical Report No. 31; 1987. 